\begin{tabular}{|l|l|l|l|l|}
$\begin{array}{l}\text { Journal of } \\
\text { Endocrinology }\end{array}$ & $\begin{array}{l}\text { Insulin receptor sensitization by } \\
\text { leflunomide }\end{array}$ & $\mathbf{2 3 7 : 1}$ & $\mathbf{4 3 - 5 8}$ \\
\hline
\end{tabular}

RESEARCH

\title{
Control of hyperglycemia in male mice by leflunomide: mechanisms of action
}

\author{
Junhong Chen',2, Jing Sun1,2, Michelle E Doscas³, Jin Ye3, Ashley J Williamson4, Yanchun Li5, Yi Lí6, \\ Richard A Prinz ${ }^{7}$ and Xiulong $X \mathbf{u}^{1,2,3,8}$ \\ 1'Institute of Comparative Medicine, Yangzhou University, Yangzhou, Jiangsu Province, China \\ ${ }^{2}$ College of Veterinary Medicine, Yangzhou University, Yangzhou, Jiangsu Province, China \\ 3Department of Cell and Molecular Medicine, Rush University Medical Center, Chicago, Illinois, USA \\ ${ }^{4}$ Rush Medical College, Rush University Medical Center, Chicago, Illinois, USA \\ ${ }^{5}$ Section of Endocrinology, Department of Medicine, University of Chicago, Chicago, Illinois, USA \\ ${ }^{6}$ Lester and Sue Smith Breast Center, Baylor College of Medicine, Houston, Texas, USA \\ 7Department of Surgery, NorthShore University Health System, Evanston, Illinois, USA \\ 8Jiangsu Co-innovation Center for Prevention and Control of Important Animal Infectious Diseases and Zoonosis, Yangzhou University, Yangzhou, China \\ Correspondence should be addressed to X Xu: xxl@yzu.edu.cn or xxu@rush.edu
}

\section{Abstract}

p70 S6 kinase (S6K1) is a serine/threonine kinase that phosphorylates the insulin receptor substrate-1 (IRS-1) at serine 1101 and desensitizes insulin receptor signaling. S6K1 hyperactivation due to overnutrition leads to hyperglycemia and type 2 diabetes. Our recent study showed that A77 1726, the active metabolite of the anti-rheumatoid arthritis (RA) drug leflunomide, is an inhibitor of S6K1. Whether leflunomide can control hyperglycemia and sensitize the insulin receptor has not been tested. Here we report that A77 1726 increased AKTS473/T308 and S6K1T389 phosphorylation but decreased S65235/236 and IRS-151101 phosphorylation in 3T3-L1 adipocytes, C2C12 and L6 myotubes. A77 1726 increased insulin receptor tyrosine phosphorylation and binding of the p85 subunit of the PI-3 kinase to IRS-1. A77 1726 enhanced insulin-stimulated glucose uptake in L6 myotubes and 3T3-L1 adipocytes, and enhanced insulin-stimulated glucose transporter type 4 (GLUT4) translocation to the plasma membrane of L6 cells. Finally, we investigated the anti-hyperglycemic effect of leflunomide on ob/ob and high-fat diet (HFD)-induced diabetes mouse models. Leflunomide treatment normalized blood glucose levels and overcame insulin resistance in glucose and insulin tolerance tests in ob/ob and HFD-fed mice but had no effect on mice fed a normal chow diet (NCD). Leflunomide treatment increased AKT ${ }^{5473 / T 308}$ phosphorylation in the fat and muscle of ob/ob mice but not in normal mice. Our results suggest that leflunomide sensitizes the insulin receptor by inhibiting S6K1 activity in vitro, and that leflunomide could be potentially useful for treating patients with both RA and diabetes.

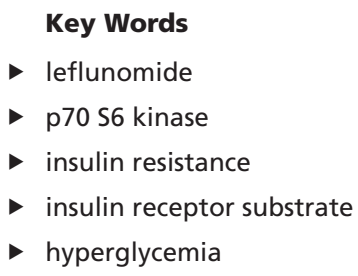

Journal of Endocrinology (2018) 237, 43-58

\section{Introduction}

Type 2 diabetes is a major public health problem (Zimmet et al. 2001, 2014). Although many anti-diabetic medications are available, some have intolerable side-effects or lose their therapeutic efficacy after the long-term use (Nathan 2015). Failure to control hyperglycemia leads to diabetic complications, which account for most diabetes-related morbidity and mortality (Nathan 2015). Because of physical inactivity and 
circulating inflammatory cytokines, diabetic patients with rheumatoid arthritis (RA) may have worse hyperglycemia than those without RA (Herlitz-Cifuentes et al. 2015, Pinto et al. 2017). Individuals with RA have a significantly higher risk of developing type 2 diabetes (Jiang et al. 2015) and obesity (Versini et al. 2014) than those without RA. Currently, patients with both RA and diabetes are treated with antidiabetic and anti-RA drugs separately. A drug that controls both RA and hyperglycemia could greatly benefit patients with both problems.

The binding of insulin to its receptor activates the insulin receptor tyrosine kinase, leading to insulin receptor autophosphorylation and the phosphorylation of intracellular protein substrates such as the insulin receptor substrates (IRS) (Fig. 1B) (Guo 2013, 2014). Tyrosinephosphorylated IRS interact with the p85 subunit of the PI-3 kinase and activate its catalytic p110 subunit (Fig. 1B). PI-3 kinase activation leads to serine phosphorylation and activation of the protein kinase B (AKT) (Guo 2013, 2014). AKT activation plays a critical role in glucose metabolism (Dann et al. 2007, Copps \& White 2012). AKT activation stimulates glucose uptake by inducing translocation of the glucose transporter type 4 (GLUT4) to the plasma membrane of both adipose and muscle cells (Fig. 1) (Guo 2013, 2014). In addition, AKT also regulates glucose metabolism by stimulating glycogen synthesis and inhibiting gluconeogenesis (Fig. 1B) (Guo 2013, 2014).

The mechanistic target of rapamycin (mTOR) kinase is a serine/threonine kinase activated by AKT. Overnutrition with high concentrations of amino acids and fatty acids also activates mTOR (Fig. 1B). p70 S6 kinase (S6K1), a serine/threonine protein kinase downstream of mTOR, phosphorylates the IRS and subsequently attenuates the activation of the PI3K pathway (Fig. 1B) (Fenton \& Gout 2010). Constitutive S6K1 activation by hyperinsulinemia or overnutrition leads to insulin receptor desensitization (Boura-Halfon \& Zick 2009, Copps \& White 2012). S6K1 is also involved in regulating the expression of several energy expenditure-related genes such as the melanocortin-4 receptor (MC4R) (Um et al. 2004, 2006, Xia et al. 2012). S6K1-l- mice do not develop obesity and hyperglycemia when fed a high-fat diet (HFD) (Um et al. 2004). These mice have a significantly longer life span than the wild-type mice (Selman et al. 2009). Insulin receptor signaling is highly active in the metabolic tissues of the HFD-fed S6K1-I- mice, as evidenced by increased AKT phosphorylation in their liver, muscle and fat (Um et al. 2004). S6K1 is a key kinase driving insulin resistance and inducing obesity under conditions of nutrient overload (Dann et al. 2007).
A<smiles></smiles>

Leflunomide

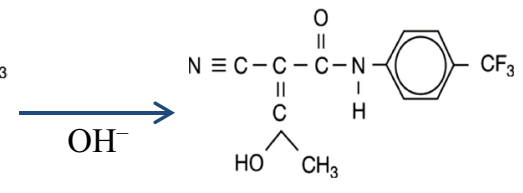

A77 1726

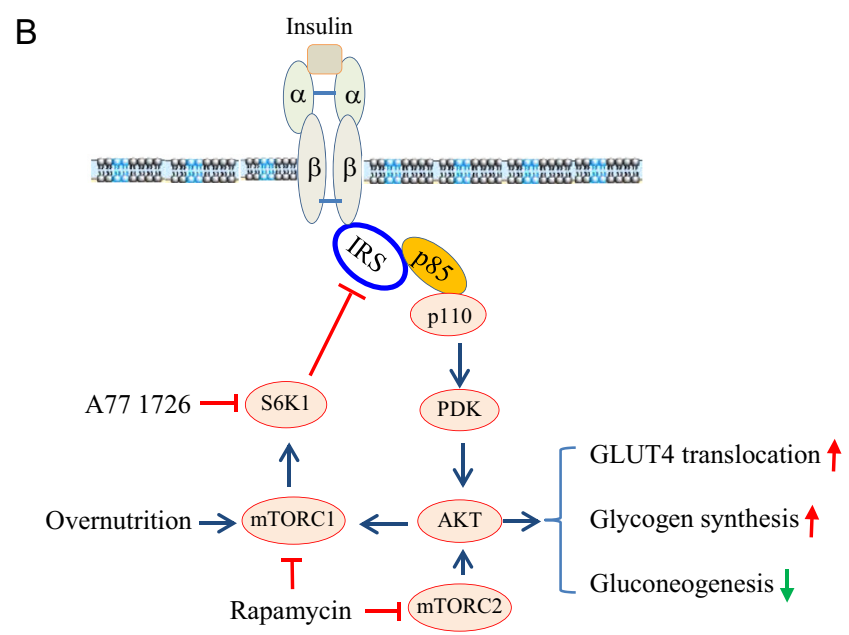

Figure 1

The mechanisms of leflunomide-mediated anti-hyperglycemic effect. (A) Chemical structure of leflunomide and A77 1726. (B) Mode of action of A77 1726. Overnutrition with high concentrations of fatty acids and amino acids leads to constitutive S6K1 activation, which phosphorylates IRS-151101, leading to poor AKT activation. Leflunomide and its active metabolite A77 1726 inhibit S6K1 activity, subsequently leading to the inhibition of IRS-151101. Inhibition of IRS-151101 phosphorylation leads to insulin receptor sensitization, as revealed by increased insulin receptor tyrosine phosphorylation and increased binding of IRS- 1 to the p85 subunit of PI-3 kinase. AKT ${ }^{5473 / 308}$ phosphorylation and activation leads to increased glucose uptake by stimulating GLUT4 membrane translocation, increased glycogen synthesis, and decreased gluconeogenesis. Chronic use of rapamycin leads to inhibition of both mTORC1 and mTORC2, thus exacerbating hyperglycemia. A full colour version of this figure is available at https://doi.org/10.1530/JOE-17-0536.

Leflunomide is an orally administered prodrug proscribed for treating rheumatoid arthritis (RA) (Breedveld \& Dayer 2000). Upon indigestion, it is rapidly and completely ( $>99 \%$ ) converted in the gastrointestinal tract, plasma and liver to its active metabolite, A77 1726 (Fig. 1A) (Breedveld \& Dayer 2000). Once in plasma, A77 1726 is avidly bound to plasma proteins, mainly albumin (Cannon \& Kremer 2004). A77 1726 has a very long halflife of 15.5 days (range 14-18 days) and is cleared after it is metabolized into trifluoromethylaniline-oxanilic acid (60-70\%) and excreted into the urine (Breedveld \& Dayer 2000, Cannon \& Kremer 2004). A77 1726 is the only active metabolite of leflunomide and is solely responsible for its therapeutic activity. A77 1726 inhibits 
the activity of protein tyrosine kinases and dihydroorotate dehydrogenase (DHO-DHase) (Xu et al. 1995, 1996, 1997, 1999, Siemasko et al. 1996, 1998, Elder et al. 1997, Ruckemann et al. 1998). The ability of A77 1726 to inhibit DHO-DHase activity (the $\mathrm{IC}_{50}$ values of approximately $100 \mathrm{nM}$ ) is about $10-100$ times stronger than its ability to inhibit the activity of protein tyrosine kinases such as p56 lck, p59 fyn and the PDGF receptor (the $\mathrm{IC}_{50}$ values of approximately 25-50 $\mu \mathrm{M}$ ) (Xu et al. 1995, 1996, 1997, 1999, Ruckemann et al. 1998). Inhibition of pyrimidine nucleotide synthesis by leflunomide was thought to be its primary mechanism of action (Williamson et al. 1996, Bruneau et al. 1998). However, addition of exogenous uridine, which normalizes pyrimidine nucleotide levels in vitro in cell cultures, only partially antagonizes this antiproliferative effect. Co-administration of uridine with leflunomide in a lymphadenopathy and autoimmune disease model of MRL/MpJ-lpr/lpr mice and in a tumor xenograft model does not abrogate the immunosuppressive and antitumor activities of leflunomide (Xu et al. 1997, 1999). This suggests that leflunomide exerts its antiproliferative and immunosuppressive activity by other mechanisms (Xu et al. 1997, 1999). Our recent study revealed that leflunomide and A77 1726 directly inhibit the activity of purified S6K1 in an in vitro kinase assay and inhibit the activity of S6K1 in cell culture, with an $\mathrm{IC}_{50}$ value of $50-75 \mu \mathrm{M}$ (4-fold lower than its plasma levels in patients) (Doscas et al. 2014). Inhibition of S6K1 activity by A77 1726 leads to feedback activation of the PI-3 kinase pathway in tumor cell lines, as evidenced by increased AKT and S6K1 phosphorylation and decreased S6 phosphorylation (Doscas et al. 2014). Here, we report that A77 1726 increases S6K1 and AKT phosphorylation and stimulates GLUT4 translocation to the cell membrane and glucose uptake in myotubes and adipocytes (Fig. 1B). We further show that leflunomide controls hyperglycemia in $o b / o b$ mice and in the mice with HFD-induced diabetes but not in normal mice.

\section{Materials and methods}

\section{Chemicals, antibodies and plasmid construct}

Leflunomide and A77 1726 were kindly provided by CinKate Corporation (Oak Park, IL, USA). Cytochalasin and rosiglitazone were purchased from Calbiochem (EMD Millipore). 3-isobutyl-1-methylxanthine (IBMX), carboxymethyl-cellulose sodium (CMC), uridine, dexamethasone and 2-deoxy-glucose (2-DG) were purchased from Sigma Aldrich. 2-DG (5-10Ci (185-370 GBq)/mmol, $1 \mathrm{mCi}$ (37 MBq) was purchased from PerkinElmer. Insulin used in the in vitro study was purchased from Invitrogen (Life Technologies). Rapamycin (an mTOR inhibitor), antibodies against AKT, S6K1, S6, IRS-1, p85 of the PI-3 kinase and phospho-antibodies (AKT $^{\text {S473 }}$, AKT ${ }^{\mathrm{T} 308}$, S6K1 ${ }^{\mathrm{T} 389}$, S6 $6^{\mathrm{S} 235 / 236}$, IRS-1 ${ }^{\mathrm{S} 1101}$, IR ${ }^{\mathrm{Y} 1146}$ and IRS-15636) were purchased from Cell Signaling Technology. Anti- $\beta$-actin monoclonal antibody was purchased from Santa Cruz Biotechnology. The sources of antibodies and their applications were listed in Table 1. mCherry-GLUT4myc expression vector was kindly provided by Dr Amira Klip (The Hospital for Sick Children, Toronto, Ontario). Use of the radioactive isotope was approved by Rush University Medical Center. All methods were performed in accordance with the relevant guidelines and regulations of Rush University Medical Center and Yangzhou University.

\section{Cell lines and differentiation}

C2C12 (a murine myoblast cell line) and L6 cells (a rat myoblast cell line) were cultured in DMEM supplemented with $10 \%$ fetal bovine serum. For myotube differentiation, the confluent monolayers of $\mathrm{C} 2 \mathrm{C} 12$ cells were cultured in DMEM containing 10\% horse serum for 2 weeks during which the same fresh medium was replenished every two days. For L6 myotube differentiation, the cells were cultured in DMEM containing $2 \%$ calf serum for two weeks. The early passages of 3T3-L1 adipocytes (within 15 passages) were differentiated according to a detailed protocol of Zebisch et al. (2012). After incubation in insulin-free medium for $7-14$ days, more than $>95 \%$ of the cells exhibited an adipocyte-like phenotype. All three cell lines were purchased from the American Type Culture Collection (ATCC).

\section{Glucose uptake}

C2C12 myotubes express very low levels of GLUT4 and therefore were not used for glucose uptake experiments. Differentiated 3T3-L1 adipocytes and L6 myotubes were incubated overnight in insulin-free DMEM medium. Cells were starved of serum for $4 \mathrm{~h}$ and then incubated in the absence or presence of A77 $1726(200 \mu \mathrm{M})$ or rapamycin $(20 \mathrm{nM})$ for $1 \mathrm{~h}$ without or with $2 \times$ amino acids in essential balanced salt solution (EBSS) for another $1 \mathrm{~h}$. Cells were left unstimulated or stimulated with $20 \mathrm{nM}$ insulin for $45 \mathrm{~min}$. Unlabeled 2-DG $(0.1 \mathrm{mM})$ and $\left[{ }^{3} \mathrm{H}\right]-\mathrm{DG}$ were added to the cells in the KRP-HEPES buffer $(10 \mathrm{mM}$ HEPES, pH7.4, $131.2 \mathrm{mM} \mathrm{NaCl}, 4.7 \mathrm{mM} \mathrm{KCl}, 1.2 \mathrm{mM}$ 
Table 1 Antibodies information.

\begin{tabular}{|c|c|c|}
\hline $\begin{array}{l}\text { Peptide/ } \\
\text { protein } \\
\text { target }\end{array}$ & $\begin{array}{l}\text { Antigen } \\
\text { sequence } \\
\text { (if known) }\end{array}$ & Name of Antibody \\
\hline AKTS473 & Unknown & Phospho-Akt (Ser473)(D9E) Ab \\
\hline AKT'308 & Unknown & Phospho-Akt (Thr308) Ab \\
\hline AKT & Unknown & Akt Antibody \\
\hline pS6K1 & Unknown & $\begin{array}{l}\text { Phospho-p70 S6 Kinase (Thr389) } \\
\text { (108D2) Ab }\end{array}$ \\
\hline S6K1 & Unknown & p70 S6 Kinase (49D7) Ab \\
\hline pS6 & Unknown & $\begin{array}{l}\text { Phospho-S6 Ribosomal Protein } \\
\text { (Ser235/236) (D57.2.2E) Ab }\end{array}$ \\
\hline S6 & Unknown & S6 Ribosomal Protein (5G10) Ab \\
\hline IRS-1S1101 & Unknown & Phospho-IRS-1 (Ser1101) Antibody \\
\hline IRS-1S636 & Unknown & Phospho-IRS-1 (Ser636/639) Antibody \\
\hline IRS-1 & Unknown & IRS-1 (59G8) Ab \\
\hline pIR & Unknown & $\begin{array}{l}\text { Phospho-IGF-I Receptor } \beta \text { (Tyr1131)/ } \\
\text { Insulin Receptor } \beta \text { (Tyr1146) Antibody }\end{array}$ \\
\hline IR & Unknown & Insulin Receptor $\beta$ (4B8) Ab \\
\hline $\mathrm{P} 85 \alpha$ & Unknown & PI3 Kinase p85 (19H8) Ab \\
\hline Actin & Unknown & $\beta$-Actin Antibody (C4) \\
\hline
\end{tabular}

\begin{tabular}{l} 
Manufacturer, catalog \#, \\
and/or name of \\
individual providing the \\
antibody \\
\hline Cell Signaling (\#4060) \\
Cell Signaling (\#9275) \\
Cell Signaling (\#9272) \\
Cell Signaling (\#9234) \\
Cell Signaling (\#2708) \\
Cell Signaling (\#4858) \\
Cell Signaling (\#2217) \\
Cell Signaling (\#2385) \\
Cell Signaling (\#2388) \\
Cell Signaling (\#2390) \\
Cell Signaling (\#3021) \\
Cell Signaling (\#3025) \\
Cell Signaling (\#4257) \\
Santa Cruz Biotechnology \\
(sc-47778)
\end{tabular}

\begin{tabular}{|c|c|}
\hline $\begin{array}{l}\text { Species raised in; } \\
\text { monoclonal or } \\
\text { polyclonal }\end{array}$ & $\begin{array}{l}\text { Dilution } \\
\text { used }\end{array}$ \\
\hline Rabbit; monoclonal & $1: 2000$ \\
\hline Rabbit; monoclonal & 1:1000 \\
\hline Rabbit; monoclonal & $1: 1000$ \\
\hline Rabbit; monoclonal & $1: 1000$ \\
\hline Rabbit; monoclonal & $1: 1000$ \\
\hline Rabbit; monoclonal & $1: 2000$ \\
\hline Rabbit; monoclonal & 1:1000 \\
\hline Rabbit; monoclonal & 1:1000 \\
\hline Rabbit; monoclonal & $1: 1000$ \\
\hline Rabbit; monoclonal & $1: 1000$ \\
\hline Rabbit; monoclonal & $1: 1000$ \\
\hline Rabbit; monoclonal & $1: 1000$ \\
\hline Rabbit; monoclonal & $\begin{array}{c}\text { WB; } 1: 1000 \\
\text { IP;1:50 }\end{array}$ \\
\hline Mouse; monoclonal & $1: 200$ \\
\hline
\end{tabular}

RRID (required in revised MSs)

AB 2315049

AB_329828

AB_329827

AB_2269803

AB_390722

AB_916156

AB_331355

AB_330363

AB_330339

$A B \_561122$

$A B \_331578$

AB_2280448

$A B \_10831521$

AB_626632

$\mathrm{MgSO}_{4}, \quad 2.65 \mathrm{mM} \quad \mathrm{CaCl}_{2}, \quad 2.5 \mathrm{mM} \quad \mathrm{NaH}_{2} \mathrm{PO}_{4}$, and $1 \%$ bovine serum albumin) at $37^{\circ} \mathrm{C}$ for $5 \mathrm{~min}$. The reaction was terminated by adding $10 \mu \mathrm{M}$ cytochalasin B followed by wash with ice-cold PBS three times. The cells were lysed in $0.2 \mathrm{M} \mathrm{NaOH}$. The radioactivity was measured in a liquid scintillation counter. Nonspecific 2-DG uptake was measured by adding cytochalasin B $(10 \mu \mathrm{M})$ into the cells prior to the addition of 2-DG. The values of 2-DG uptake, after correction by subtracting the value of the non-specific 2-DG uptake, were normalized by protein concentrations, which were quantified by using a Bio-Rad Protein Assay kit (Bio-Rad).

\section{Western blot}

C2C12 myotubes grown in 6-well plates were starved of serum for $4 \mathrm{~h}$. A77 1726 or rapamycin was added and incubated for $2 \mathrm{~h}$. Cells were left unstimulated or stimulated with $20 \mathrm{nM}$ insulin for $20 \mathrm{~min}$. Differentiated 3T3-L1 adipocytes and L6 myotubes were treated as described in the glucose uptake experiments. Cell lysates were prepared in NP-40 lysis buffer $(50 \mathrm{mM}$ Tris-HCl (pH 8.0), $150 \mathrm{mM} \mathrm{NaCl}, 1 \% \mathrm{NP}-40,5 \mathrm{mM}$ EDTA, $10 \mu \mathrm{g} / \mathrm{mL}$ aprotinin, $10 \mu \mathrm{g} / \mathrm{mL}$ leupeptin, and $1 \mathrm{mM}$ phenylmethylsulfonyl fluoride, $2 \mathrm{mM}$ sodium vanadate) and analyzed for protein phosphorylation with the indicated antibodies, followed by reprobing with antibodies against total proteins. The density of the bands was analyzed by using NIH ImageJ software and normalized by the arbitrary units of their corresponding total proteins. Quantified results were presented as the mean \pm standard deviation (s.D.) from three experiments (Figs 2, 3, 4 and 5) in bar graphs.

\section{Immunoprecipitation}

L6 myotubes and 3T3-L1 adipocytes were first starved of serum for $2 \mathrm{~h}$ or overnight, respectively, then incubated either in an amino-acid free medium (EBSS) or EBSS medium containing $2 \times$ amino acids $(2 \times \mathrm{AA})$ in the absence or presence of A77 1726 for $5 \mathrm{~h}$. Cells were left unstimulated or stimulated with insulin (100 nM) for $10 \mathrm{~min}$. Cell lysates were immunoprecipitated with a rabbit monoclonal antibody against the p85 subunit of the PI-3 kinase, followed by probing with anti-p85 and anti-IRS1 antibodies in Western blot.

\section{Confocal microscopy}

Undifferentiated L6 cells seeded on coverslips were transiently transfected with mCherry-GLUT4-myc expression vector DNA using FuGENE6 following the manufacturer's protocol. After incubation for $24 \mathrm{~h}$, the cells were starved of serum for $2 \mathrm{~h}$ and then incubated in the absence or presence of A77 $1726(200 \mu \mathrm{M})$ for $4 \mathrm{~h}$ without or with $2 \times$ the amino acid concentrations in EBSS. Cells were left unstimulated or stimulated with $100 \mathrm{nM}$ insulin for $30 \mathrm{~min}$. The coverslips were collected, 
fixed and mounted with 50\% glycerin in PBS containing 4,6-diamidino-2-phenylindole (DAPI) $(0.5 \mu \mathrm{g} / \mathrm{mL}$; Sigma Chemical). mCherry-tagged GLUT4 fluorescence was visualized under a Leica LP8 confocal microscope. The percent of cells positive for GLUT4 translocation into the plasma membrane among total mCherry-GLUT4expressing cells was calculated by counting 10 randomly selected fields from each treatment. The results represent the mean \pm standard deviation (s.D.) from one of three experiments with similar results.

\section{Animals and drug administration}

Use of animals and all experimental protocols were approved by the Institutional Animal Care and Use Committee of Rush University Medical Center and College of Veterinary Medicine, Yangzhou University. All mice were maintained on a 12-h light/darkness cycle and housed in ventilated cages at an ambient temperature of $23^{\circ} \mathrm{C}$. Male $o b / o b$ mice (B6.V-Lepob/OlaHsd, male) were purchased from Harlan Laboratories, Inc. These mice were fed ad libitum on a normal chow diet (NCD). CMC (1.5\% dissolved in distilled water) was used as a vehicle to prepare leflunomide. Mice (8-10-week-old) were given $1.5 \% \mathrm{CMC}$ or leflunomide by gavage. Uridine was co-administered with leflunomide to $o b / o b$ mice to determine whether leflunomide could still control hyperglycemia when pyrimidine nucleotide levels in various tissues were normalized. The uridine dose was based on our previous studies (Xu et al. 1997, 1999) that $2 \mathrm{~g} / \mathrm{kg}$, twice daily is sufficient to normalize or overshoot pyrimidine nucleotide levels in the fast proliferating tumor cells or lymphocytes of $l p r / l p r$ mice. Uridine dissolved in saline was given by intraperitoneal (i.p.) injection. $o b / o b$ mice were treated with the vehicle (1.5\% CMC daily), leflunomide $(35 \mathrm{mg} / \mathrm{kg} /$ day, daily, gavage), uridine $(2 \mathrm{~g} / \mathrm{kg}$, twice daily, i.p.) or leflunomide $(35 \mathrm{mg} / \mathrm{kg} / \mathrm{day}$, daily, gavage $)+$ uridine $(2 \mathrm{~g} / \mathrm{kg}$, twice daily, i.p.) for
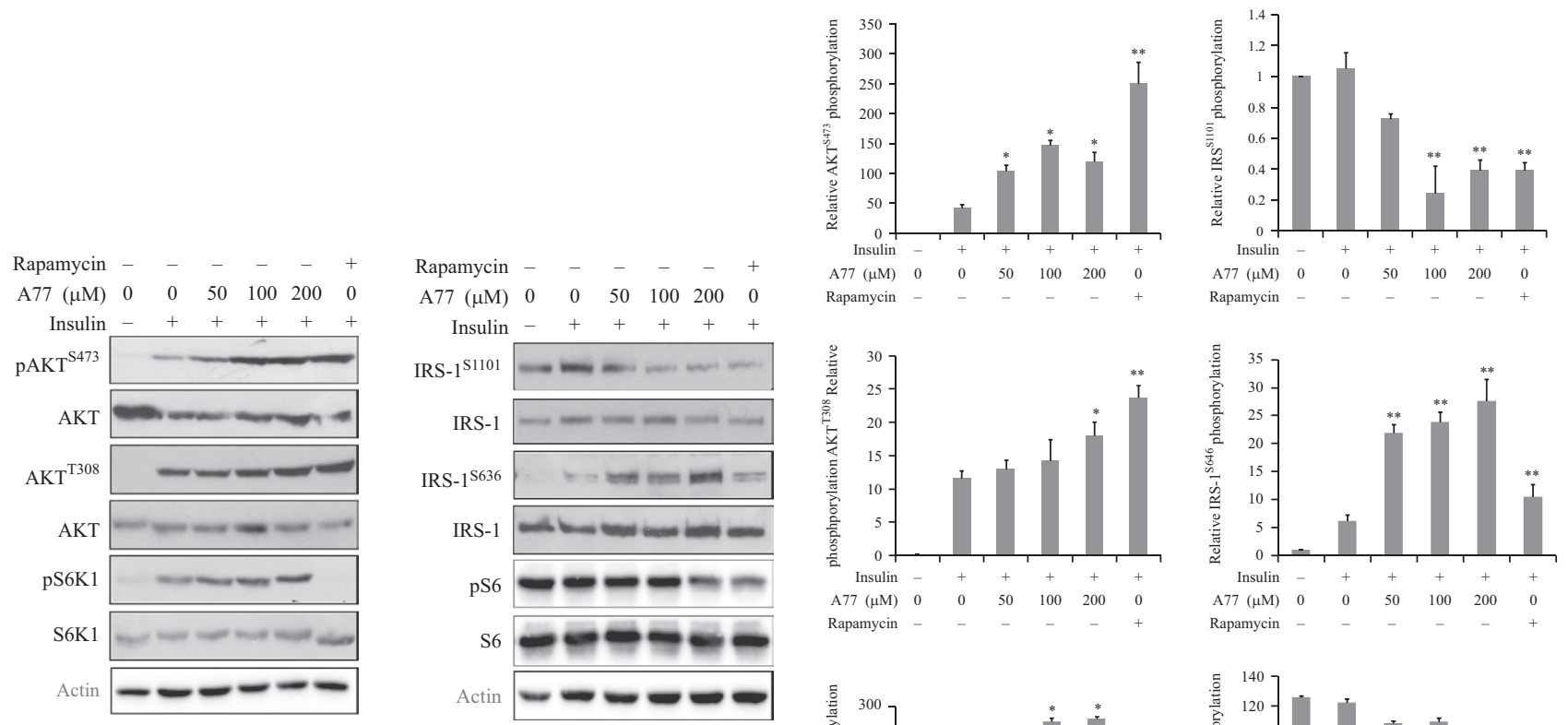

Rapamycin

Rapamycin
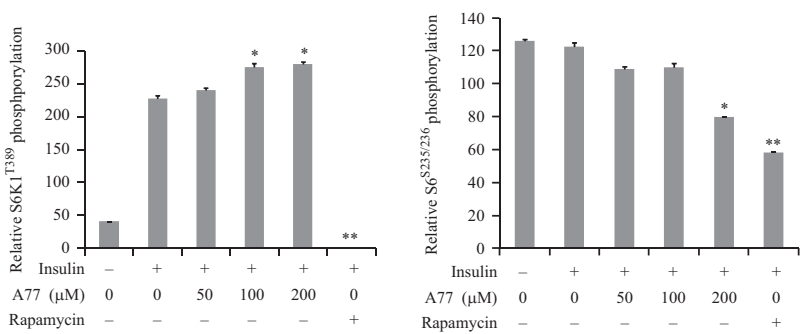

\section{Figure 2}

Effect of A77 1726 on protein phosphorylation in the PI-3 kinase pathway. C2C12 myotubes were starved in serum-free medium for $4 \mathrm{~h}$ and then treated with the indicated concentrations of A77 1726 or rapamycin ( $50 \mathrm{nM})$ for $2 \mathrm{~h}$. The cells were left unstimulated or stimulated with insulin (20 $\mathrm{nM}$ ) for $20 \mathrm{~min}$. Cells were harvested and analyzed for the phosphorylation of AKTS473, AKTT308, and S6K1T389, IRS-151101, IRS-15636, and S65235/236, followed by reprobing with their specific antibodies for total protein levels. Relative protein phosphorylation was determined by analyzing the density of bands and presented as bar graphs. The results are the mean \pm standard deviation (s.D.) from three experiments. A77, A77 1726; $* P<0.05 ; * * P<0.01$, compared to the insulin-stimulated control (no drug treatment). 
A
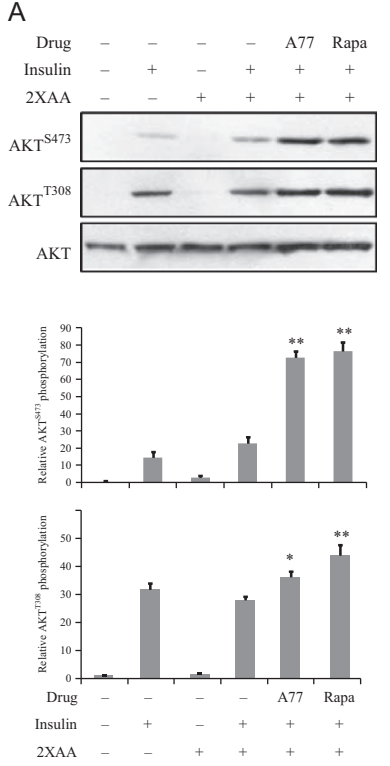

B
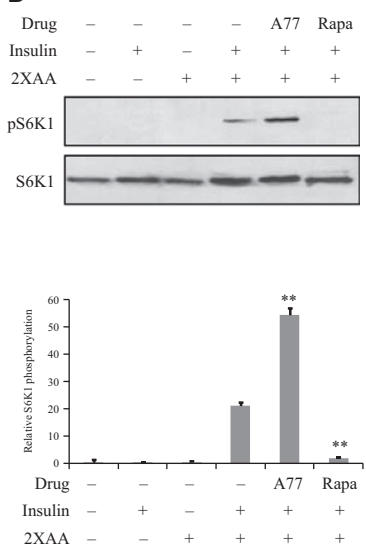

C
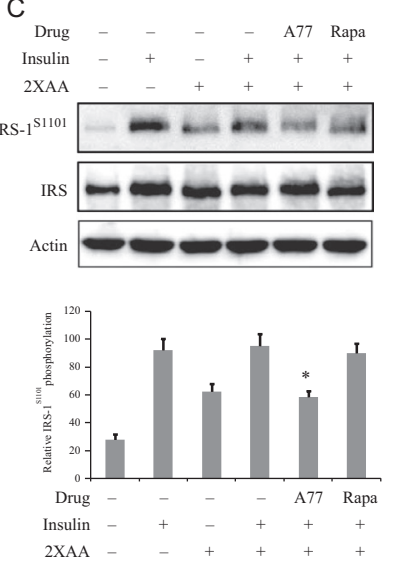
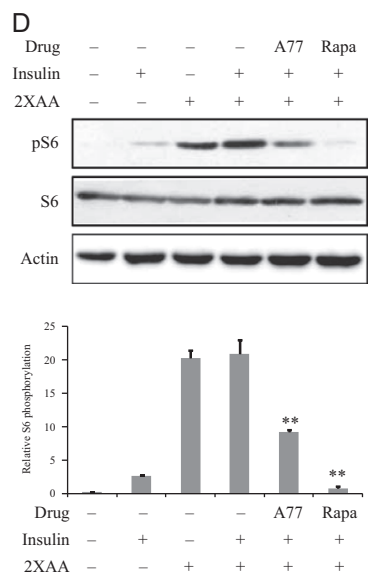

Figure 3

A77 1726 sensitizes insulin receptor in L6 myotubes. This experiment and the remaining ones (Figs 4, 5, 6 and 7) were carried out under the condition of insulin resistance in which the cells were incubated in the presence of high concentrations of amino acids. L6 myotubes were first starved of serum for $4 \mathrm{~h}$ and then incubated either in an amino-acid free medium (EBSS) or EBSS medium containing $2 \times$ the amino acid concentrations ( $2 \times A A$ ) found in MEM in the absence or presence of A77 $1726(200 \mu \mathrm{M})$ for $2 \mathrm{~h}$. After stimulation with insulin $(20 \mathrm{nM})$ for $20 \mathrm{~min}$, cells are harvested and analyzed for the phosphorylation of $A K T^{5473 / 308}$ (A), S6K1T389 (B), IRS-151101 (C), S65235/236 (D), and reprobed with their specific antibodies for total proteins. Relative protein phosphorylation was analyzed by using an Image J software. The results are the mean \pm s.D. from three experiments. A77, A77 1726; Rapa, rapamycin. ${ }^{*} P<0.05 ; * * P<0.01$, compared to the control (with insulin and $2 \times$ amino acids but without drug).

three days. After fasting $6 \mathrm{~h}$, blood was sampled from the tail vein and analyzed by a Bayer handheld glucometer. Body weight of mice was measured before and 3 days after treatment. Food intake was measured in the individual cages on day 3 after treatment.

For the glucose tolerance test (GTT) and insulin tolerance test (ITT), mice were treated for 3 days as above. On day 4 , mice were fasted and treated with a last dose $6 \mathrm{~h}$ before GTT. Mice were challenged with glucose $(1 \mathrm{~g} / \mathrm{kg})$ by intraperitoneal injection. For ITT, mice were similarly treated and fasted for $6 \mathrm{~h}$, followed by intravenous injection of insulin $(2.5 \mathrm{unit} / \mathrm{kg})$ into the tail vein. Blood glucose levels were measured at various time points between 0 and $120 \mathrm{~min}$ (GTT) or between 0 and $60 \mathrm{~min}$ (ITT) by using a Bayer glucometer. AUC (area under curve) of the glucose levels in the GTT and ITT was calculated by using GraphPad Prism 5 software. AUC was plotted as bar graphs.

C57BL/6 male mice were purchased from the Center for Comparative Medicine, Yangzhou University. Mice ( 5 weeks old) were fed with NCD or HFD ( $24 \%$ fat, $24 \%$ protein, $41 \%$ carbohydrates, $1 \%$ others by weight, which translate to calories percentage as $20 \%$ protein, $35 \%$ carbohydrate, $45 \%$ fat) (Jiangsu Medicience Ltd, Yangzhou, China) for 10 weeks. Mice were treated with
CMC or leflunomide followed by GTT as described earlier. ITT in C57BL/6 mice fed either NCD or HFD was conducted similarly as above except insulin $(2.5 \mathrm{unit} / \mathrm{kg})$ was intraperitoneally injected.

\section{In vivo $\mathrm{AKT}$ activation}

$o b / o b$ mice were treated daily for three days. They were given a last dose on day 4 and then fasted for $6 \mathrm{~h}$. Five minutes after insulin injection ( $2.5 \mathrm{unit} / \mathrm{kg}$, intravenously), mice were sacrificed. Gastrocnemius muscle, mesenteric visceral white adipose and hepatic tissues (50-100 mg/sample) were collected and immediately homogenized in NP-40 lysis buffer. Protein concentrations were measured using a Pierce BCA Protein Assay kit (Thermo Fisher Scientific). AKT ${ }^{\text {S473/T308, S6 }} 6^{\text {S235/236 }}$ and IRS-1 ${ }^{\text {S1101 }}$ phosphorylation was analyzed by Western blot. The density of the bands was analyzed by using NIH ImageJ software and normalized by the arbitrary units of their corresponding total proteins.

\section{Statistical analysis}

Data were presented as mean \pm standard deviation (s.D.) (glucose uptake and GLUT4 translocation assays) or standard error of the mean (s.E.M.) (blood glucose levels). 


\begin{tabular}{l|l|l|l|l|}
$\begin{array}{l}\text { Journal of } \\
\text { Endocrinology }\end{array}$ & J Chen et al. & $\begin{array}{l}\text { Insulin receptor sensitization by } \\
\text { leflunomide }\end{array}$ & $\mathbf{2 3 7 : 1}$ & $\mathbf{4 9}$ \\
\hline
\end{tabular}
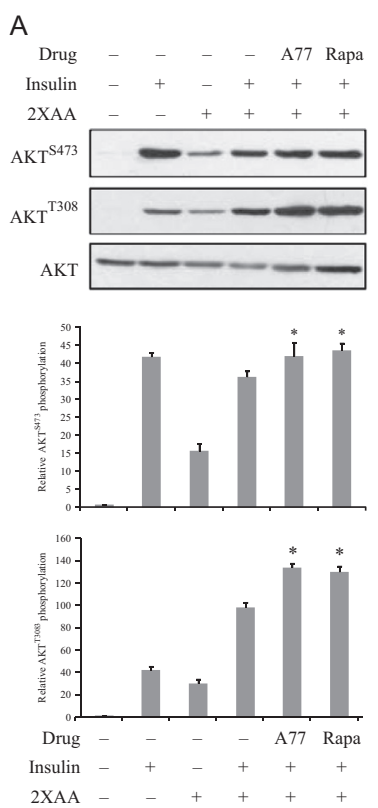

B
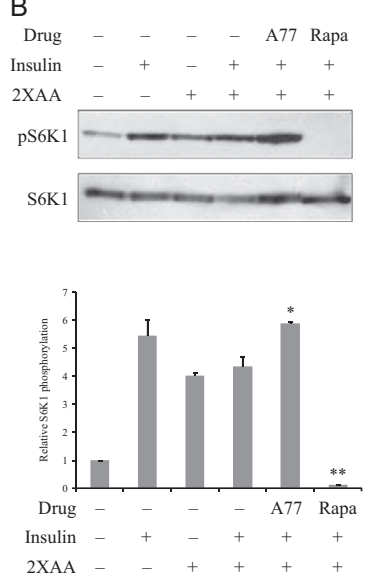

C
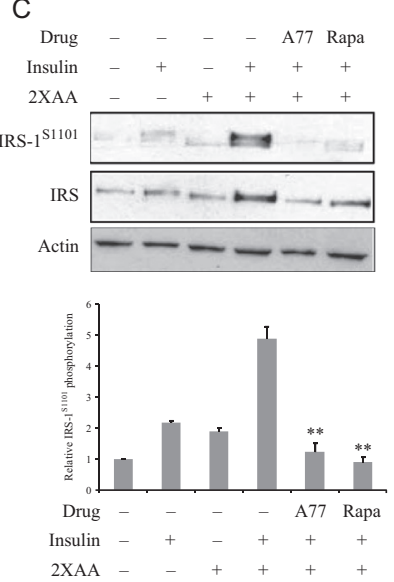
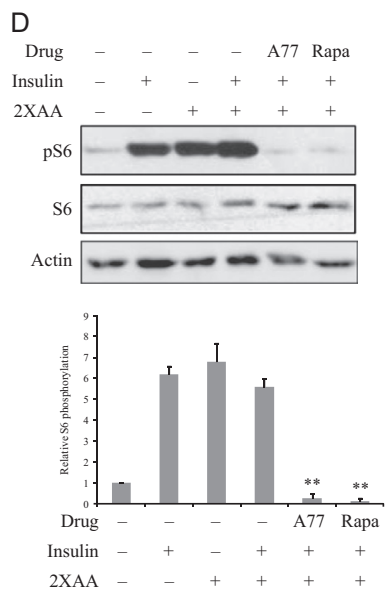

Figure 4

A77 1726 sensitizes insulin receptor in 3T3-L1 adipocytes. 3T3-L1 adipocytes were treated in Fig. 3 and then incubated either in an amino-acid free medium (EBSS) or EBSS medium containing $2 \times$ the amino acid concentrations ( $2 \times A A)$ found in MEM in the absence or presence of A77 1726 for $2 \mathrm{~h}$. Cells were stimulated with insulin ( $20 \mathrm{nM})$ for $20 \mathrm{~min}$. The cells were harvested and analyzed for the phosphorylation of AKT5473/308 (A), S6K1T389 (B), IRS-151101 (C), 565235/236 (D), and reprobed with their specific antibodies for total proteins. The density of bands was analyzed by using an NIH Image-J software and normalized by the arbitrary units of their corresponding total proteins. The results are the mean \pm s.D. from three experiments. A77, A77 1726; Rapa, rapamycin. ${ }^{*} P<0.05 ;{ }^{*} P<0.01$, compared to the control (with insulin and $2 \times$ amino acids but without drug).

An unpaired Student $t$ test was used to analyze the differences in glucose uptake in 3T3-L1 adipocytes and L6 myotubes in different groups, and the differences in the arbitrary number of Western blot data from the ImageJ analysis. Differences in blood glucose levels between different treatment groups were analyzed by repeatedmeasures ANOVA (analysis of variance). Differences in blood glucose levels in individual groups before and after treatment were statistically analyzed by a paired Student $t$ test. A $P$ value $<0.05$ was considered statistically significant. All statistics was performed with SigmaPlot 11 software (Systat Software, San Jose, CA, USA).

\section{Results}

\section{A77 1726 induces feedback activation of the PI-3 kinase pathway}

S6K1 inhibition by A77 1726 in tumor cell lines leads to feedback activation of the PI-3 kinase pathway through the insulin-like growth factor 1 (IGF-1) receptor (Doscas et al. 2014). Here, we tested if A77 1726 also induced feedback activation of the PI-3 kinase pathway in C2C12 myotubes. As shown in Fig. 2, insulin induced the phosphorylation of IRS-15636, AKTT308, AKT ${ }^{\mathrm{S} 733}$ and S6K1 ${ }^{\mathrm{T} 389}$ in C2C12 myotubes. A77 1726 enhanced insulin-induced phosphorylation of $\mathrm{AKT}^{\mathrm{S} 473}$, AKT ${ }^{\mathrm{T} 308}$ and $\mathrm{S} 6 \mathrm{~K}^{\mathrm{T} 389}$, but inhibited the phosphorylation of S65235/236 and IRS ${ }^{51101}$, both of which are phosphorylated by S6K1. In contrast, A77 1726 increased the phosphorylation of IRS\$636 (Fig. 2). This site is phosphorylated largely by mTOR. Of note, S6 $6^{\text {S235/236 }}$ and IRS-151101 were highly phosphorylated in unstimulated C2C12 myotubes. Rapamycin, an inhibitor of mTOR, increased AKT ${ }^{308}$ and AKT A $^{543}$ phosphorylation

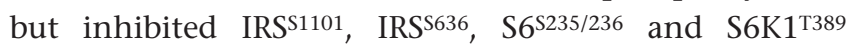
phosphorylation. Increased S6K1 phosphorylation by A77 1726 is consistent with previous observations with PF-4708671, a specific S6K1 inhibitor (Pearce et al. 2010, Shum et al. 2016).

\section{A77 1726 enhances insulin receptor signaling}

We next examined the effect of A77 1726 on protein phosphorylation in the PI-3 kinase pathway in L6 myotubes and 3T3-L1 adipocytes in the presence of high amino acid concentrations, a condition of insulin resistance. As shown in Fig. 3, insulin induced AKT ${ }^{5473 / 7308}$ phosphorylation in the absence of amino acids in L6 myotubes. Consistent with previous observations (Patti et al. 1998), high amino 
A
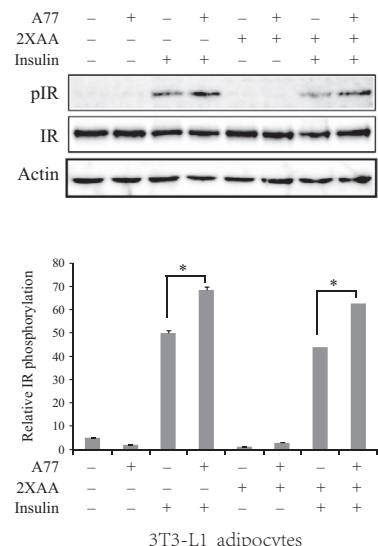

B
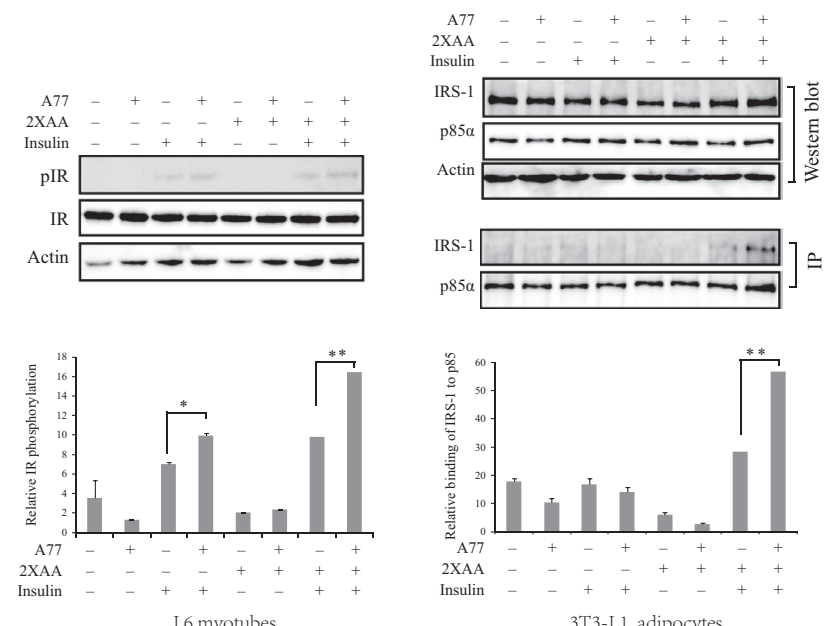
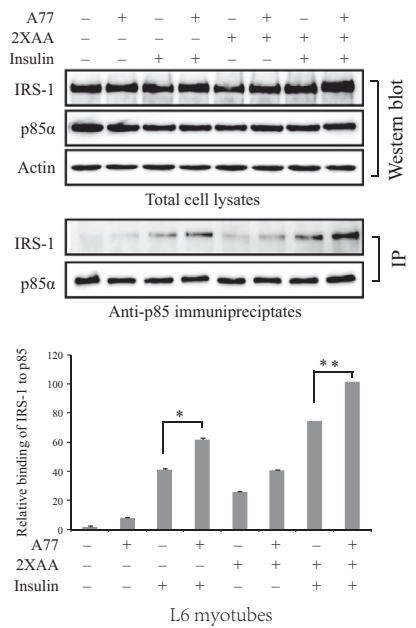

Figure 5

A77 1726 stimulates insulin receptor tyrosine phosphorylation and increases the insulin receptor substrate (IRS-1) binding to the p85 $\alpha$ subunit of the PI-3 kinase. (A) 3T3-L1 adipocytes and L6 myotubes were similarly treated as in Fig. 3 and analyzed for the phosphorylation of insulin receptor tyrosine phosphorylation at Y1146. (B) A77 1726 increases the binding of the p85 subunit of the PI-3 kinase to IRS-1. 3T3-L1 adipocytes and L6 myotubes were treated in Fig. 3. Cell lysates were immunoprecipitated with an anti-p85 antibody followed by probing with anti-p85 and anti-IRS-1 antibodies in Western blot. Relative protein phosphorylation was analyzed by using Image J software. The results are the mean \pm s.D. from three experiments. A77, A77 1726; *P<0.05; **P<0.01

acids activated S6K1, as revealed by increased S65235/236 and IRS-151101 phosphorylation, which is considered the indirect evidence of insulin resistance. A77 1726 induced phosphorylation of S6K1, which is a downstream molecule of mTOR, whereas rapamycin inhibited it. Both A77 1726 and rapamycin inhibited IRS-1 ${ }^{\text {S1101 }}$ and S6 $6^{\text {S235/236 }}$ phosphorylation but increased AKT $^{5473}$ and AKT ${ }^{\mathrm{T} 308}$ phosphorylation in L6 myotubes. Similar results were obtained in 3T3-L1 adipocytes (Fig. 4).

Um et al. (2004) reported that S6K1 deficiency leads to insulin receptor sensitization, as evidenced by increased insulin receptor tyrosine phosphorylation in the liver of insulin-treated mice, compared to that in wild-type mice. Here, we tested if A77 1726 could indeed enhance insulin receptor signaling. 3T3-L1 adipocytes and L6 myotubes preincubated with A77 1726 in the absence or presence of $2 \times$ amino acids and were left unstimulated or stimulated with insulin for $30 \mathrm{~min}$. As shown in 5A, insulin-induced insulin receptor tyrosine phosphorylation in 3T3-L1 adipocytes and L6 myotubes that were cultured in the absence or presence of high concentrations of amino acids. This phosphorylation was further increased by A77 1726. Immunoprecipitation revealed that insulin stimulation increased the binding of the p85 subunit of the PI-3 kinase to IRS-1 in 3T3-L1 adipocytes and L6 myotubes cultured in the absence or presence of $2 \times$ amino acids. This binding was further increased by A77 1726 (Fig. 5B). Cell lysates were analyzed by Western blot. Equal levels of IRS- 1 and the p85 subunit of the PI-3 kinase were found in the cell lysates used for immunoprecipitation (Fig. 5B).

\section{A77 1726 increases GLUT4 translocation to the cell membrane}

AKT activation induces the translocation of GLUT4 from the vesicles into the plasma membrane (Dann et al. 2007, Copps \& White 2012). GLUT4 was detected in the cytoplasm of unstimulated L6 but was translocated to the plasma membrane in insulin-stimulated cells in the absence of amino acids (Fig. 6). A77 1726 alone slightly increased GLUT4 membrane translocation in L6 cells in the presence of $2 \times$ amino acids. Insulin also weakly induced GLUT4 translocation into the plasma membrane in the presence of $2 \times$ amino acids, almost as well as in the absence of $2 \times$ amino acids, probably due to the use of the undifferentiated L6 myoblast cells in this experiment. Alternatively, the relatively low transfection efficiency and a few GLUT4-positive cells under a high power field may shield the $2 \times$ amino acids-mediated inhibition of GLUT4 translocation. Nevertheless, A77 1726 significantly increased insulin-stimulated GLUT4 membrane translocation in L6 cells in the presence of $2 \times$ the amino acid concentrations (Fig. 6). 
A
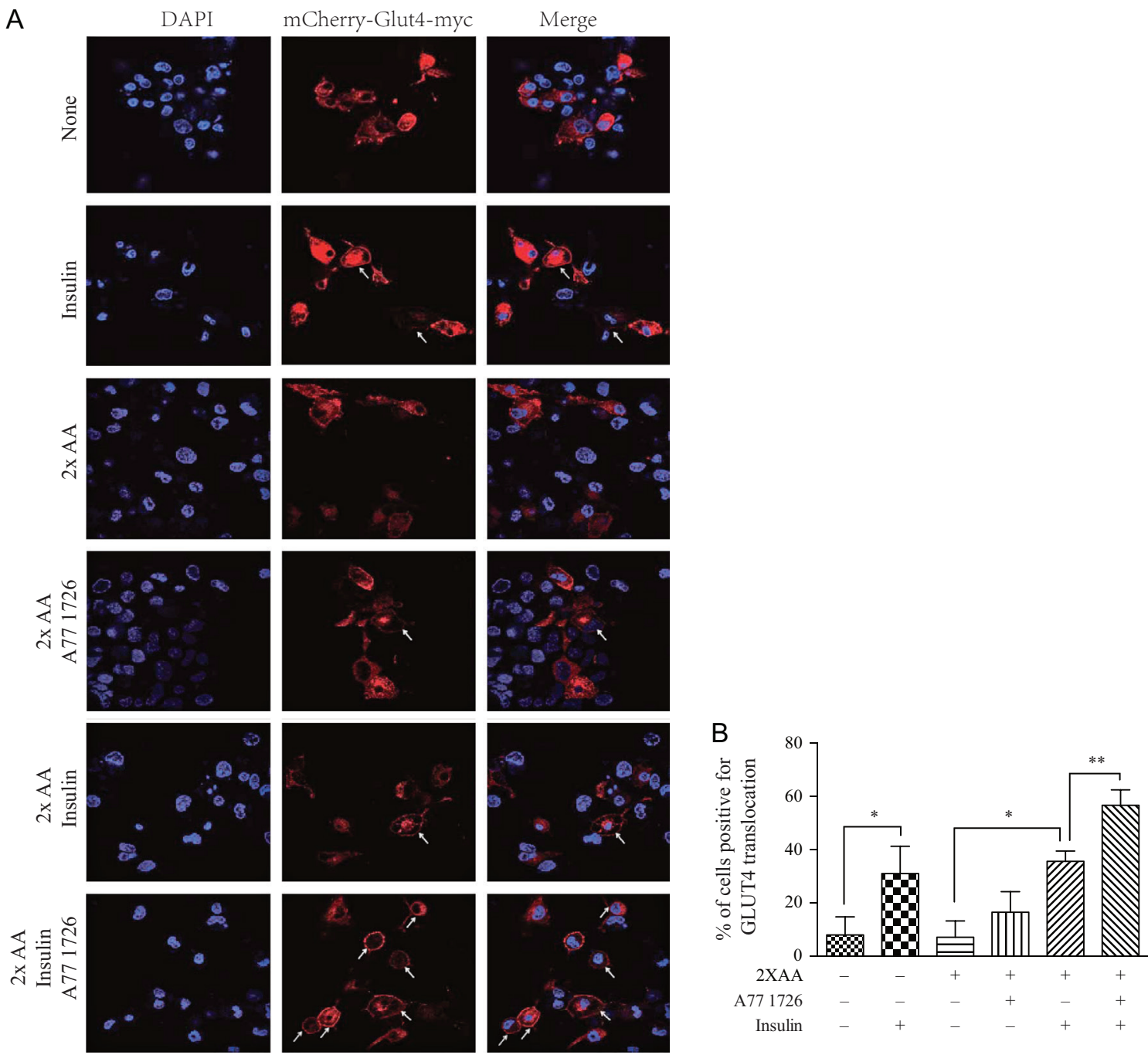

\section{Figure 6}

A77 1726 enhances insulin-induced GLUT4 translocation to the plasma membrane. (A) GLUT4 translocation to the plasma membrane. mCherry-GLUT4myc-transfected L6 cells were starved of serum for $4 \mathrm{~h}$ and then incubated in the absence or presence of A77 $1726(200 \mu \mathrm{M})$ without or with $2 \times$ the amino acid concentrations. Cells were left unstimulated or stimulated with $20 \mathrm{nM}$ insulin for $45 \mathrm{~min}$. After fixation in methanol for $10 \mathrm{~min}$, $\mathrm{mCherry}-$ tagged GLUT4 fluorescence was visualized under a Leica LP8 confocal microscope. Arrows denote the mCherry-tagged GLUT4 translocation to the cell membrane. (B) Quantification of the GLUT4 translocation to the plasma membrane. The data represent the mean \pm S.D. from one of three experiments with similar results. ${ }^{*} P<0.05 ;{ }^{*} P<0.01$. A full colour version of this figure is available at https://doi.org/10.1530/JOE-17-0536.

\section{A77 1726 increases glucose uptake}

We next determined if insulin receptor sensitization by A77 1726 led to increased glucose uptake. Cells treated with high concentrations of amino acids were considered under the insulin resistance condition. Indeed, $2 \times$ the amino acid concentrations significantly decreased the basal level of glucose uptake in L6 myotubes by $29 \%$ and reduced insulin-stimulated glucose uptake by $22 \%$, compared to their corresponding controls (Fig. 7A). A77 1726 increased insulin-stimulated glucose uptake in the presence of $2 \times$ the amino acid concentrations by $31 \%$. Rapamycin included as a positive control increased glucose uptake by $19 \%$ (Fig. 7A) in insulin-stimulated L6 myotubes in the presence of $2 x$ the amino acid concentrations. Slightly better stimulation of insulininduced glucose uptake by A77 1726 was observed with 3T3-L1 adipocytes (Fig. 7B). Of note, A77 1726 is a cytostatic drug and does not affect the viability and proliferation of differentiated non-dividing cells. Cells were incubated in the presence of A77 1726 only for a few hours. Using an Enhanced Cell Counting Kit-8 (CCK-8), we found that A77 $1726(200 \mu \mathrm{M})$ did not have any cytotoxicity on 3T3-L1 adipocytes and L6 myotubes http://joe.endocrinology-journals.org https://doi.org/10.1530/JOE-17-0536 (c) 2018 Society for Endocrinology Published by Bioscientifica Ltd. Printed in Great Britain 


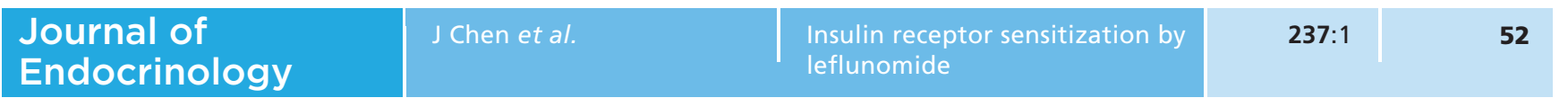

A

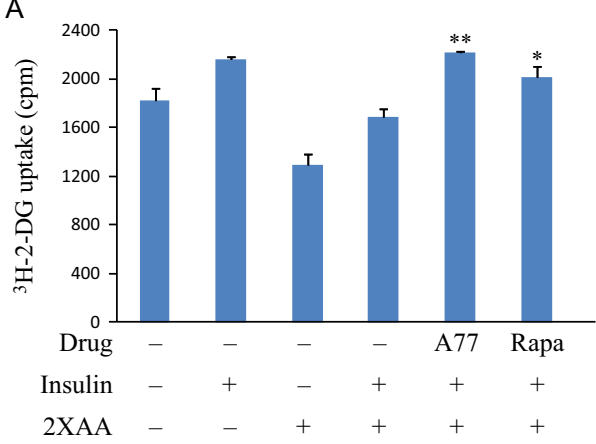

B

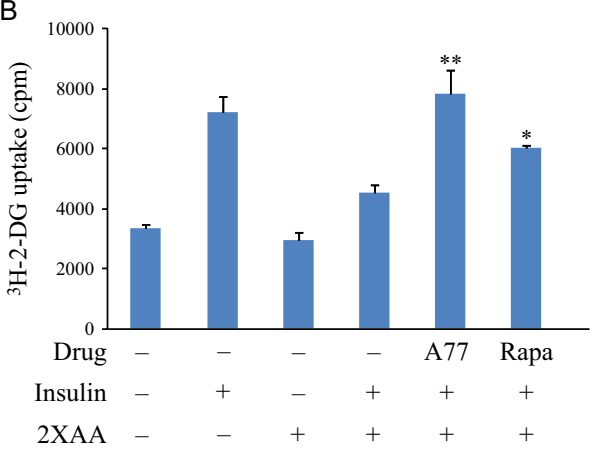

\section{Figure 7}

A77 1726 increases glucose uptake. L6 myotubes (A) and 3T3-L1 adipocytes (B) seeded in 24-well plates were starved in serum-free, low glucose DMEM medium for $4 \mathrm{~h}$. The cells were then incubated in EBSS in the absence or presence of $2 \times A A$ and/or A77 $1726(200 \mu \mathrm{M})$ or rapamycin $(50 \mathrm{nM})$ for $2 \mathrm{~h}$. The cells were left unstimulated or stimulated with $20 \mathrm{nM}$ insulin for $45 \mathrm{~min}$ followed by incubation of $\left[{ }^{3} \mathrm{H}\right]-2-\mathrm{DG}$ for $5 \mathrm{~min}$. The data are the mean \pm S.D. of the triplicate in one of three experiments with similar results. $* P<0.05 ; * * P<0.01$, compared to the control (with insulin and $2 \times$ amino acids but without drug).

(data not shown). Using a CellTiter-Glo Luminescent Cell Viability Assay, we found that A77 $1726(200 \mu \mathrm{M})$ reduced the proliferation of 3T3-L1 adipocytes by approximately $20 \%$ after incubation for $48 \mathrm{~h}$ (data not shown).

\section{Control of hyperglycemia by leflunomide}

We first assessed the ability of leflunomide to control hyperglycemia in male mice since estrogen in female mice may protect against high-fat diet-induced metabolic syndrome. Female animals are prone to adipose tissue storage and glucose homeostasis, whereas males are predisposed to diabetes. As shown in Table 2, blood glucose levels were very high ( $>200 \mathrm{mg} / \mathrm{dL}$ ) in $o b / o b$ mice before treatment and remained very high in mice treated with CMC, a vehicle used to dissolve leflunomide. Fasting blood glucose levels decreased to normal levels in mice treated with leflunomide alone or with leflunomide plus uridine $(<110 \mathrm{mg} / \mathrm{dL})$. Statistical analysis revealed that leflunomide treatment significantly lowered blood glucose levels $(P<0.01)$. Treatment with uridine, a nucleoside used to normalize pyrimidine nucleotide levels in vitro and in vivo (Xu et al. 1997, 1999), had no effect on fasting blood glucose levels and did not block leflunomide-mediated control of hyperglycemia. These observations suggest that leflunomide controls hyperglycemia independent of its inhibitory effect on pyrimidine nucleotide synthesis. There were no significant differences in food intake and body weight among mice treated with $\mathrm{CMC}$, leflunomide, uridine or leflunomide plus uridine for 3 days (Table 2).

We next conducted GTT to examine the ability of leflunomide to lower blood glucose levels in $o b / o b$ mice. Blood glucose levels in mice receiving leflunomide or leflunomide plus uridine were significantly lower than those treated with CMC $(P<0.001)$ (Fig. 8A). Uridine treatment alone did not significantly alter blood glucose levels in mice. ITT assay revealed that blood glucose levels were elevated in control mice or in mice treated with uridine $15 \mathrm{~min}$ after insulin injection (Fig. 8C). In contrast, insulin did not increase blood glucose levels in leflunomide-treated mice but was able to slightly increase blood glucose levels in mice treated with uridine plus leflunomide (Fig. 8C). Transient increase of blood glucose levels after insulin injection into the tails of control $o b / o b$ mice is probably caused by stress or due to the insulin receptor internalization. Transient increase of blood glucose levels after insulin injection is consistent with observations made by others (He et al. 2013). AUC was significantly decreased in leflunomide- or leflunomide plus uridine-treated mice, compared to those treated with $\mathrm{CMC}$ or uridine alone (Fig. $8 \mathrm{~B}$ and $\mathrm{D})(P<0.01)$. Consistently, leflunomide treatment significantly decreased blood glucose levels in GTT (Fig. 8E and F) and ITT assays (Fig. 8G and H) in HFD-fed mice, compared to those treated with CMC. Leflunomide appears more effective in lowering blood glucose levels in $o b / o b$ mice while only modestly lowering blood glucose levels in the mice with HFD-induced diabetes. Leflunomide treatment did not significantly alter blood glucose levels in mice fed a NCD (Fig. 8E, F, G and H).

Finally, we tested if leflunomide treatment enhanced insulin receptor signaling in vivo in $o b / o b$ mice. As shown in Fig. 9A, insulin significantly increased AKT ${ }^{\text {4473/T308 }}$ phosphorylation in the muscle, fat and liver of normal mice, compared to the unstimulated controls $(P<0.05)$ (Fig. 9C). Leflunomide treatment did not or only slightly enhanced insulin-induced AKT phosphorylation in these insulin-sensitive tissues of control mice. The levels of AKT $^{\text {s473/T308 }}$ phosphorylation in the tissue of the control 


\begin{tabular}{|l|l|l||c|}
$\begin{array}{l}\text { Journal of } \\
\text { Endocrinology }\end{array}$ & J Chen et al. & $\begin{array}{l}\text { Insulin receptor sensitization by } \\
\text { leflunomide }\end{array}$ & $\mathbf{2 3 7 : 1}$ \\
\hline
\end{tabular}

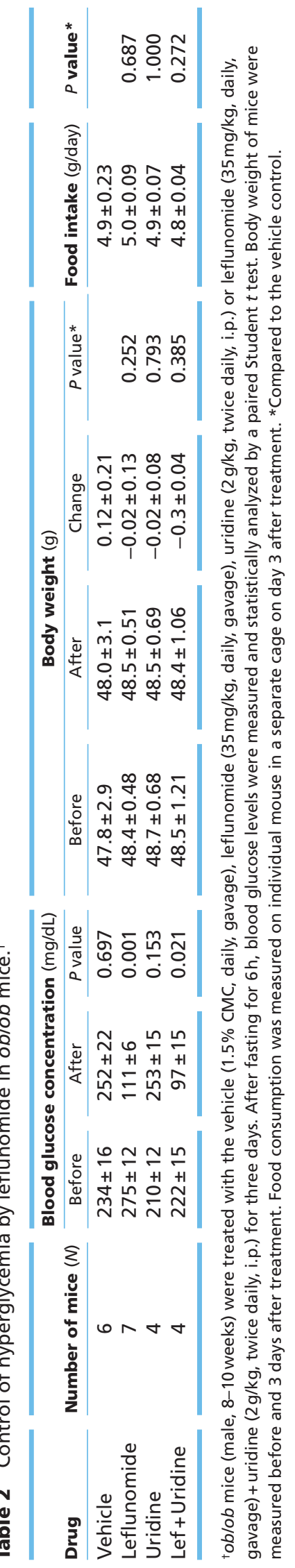

http://joe.endocrinology-journals.org https://doi.org/10.1530/JOE-17-0536
(C) 2018 Society for Endocrinology Published by Bioscientifica Ltd. and leflunomide-treated mice were comparable (Fig. 9A and C) $(P>0.05)$. In contrast, insulin poorly induced AKT ${ }^{5473 / T 308}$ phosphorylation in the muscle, fat and liver of $o b / o b$ mice (Fig. 9B). Densitometry analysis revealed that AKT $^{5473 / T 308}$ phosphorylation in the insulin-sensitive tissue was not significantly different between the untreated and insulin-treated mice $(P>0.05)$ (Fig. 9D). Leflunomide treatment significantly increased insulin-stimulated AKT $5473 / 7308$ phosphorylation in the muscle and adipose tissues, compared to those mice treated with the control vehicle only $(P<0.05)$. AKT ${ }^{5473 / T 308}$ phosphorylation levels appeared to be higher in the liver of leflunomide-treated $o b / o b$ mice than that of untreated ob/ob mice. However, statistical analysis did not reach significance. Similarly, AKT ${ }^{5473 / 7308}$ phosphorylation levels were also higher in the muscle, fat and liver of $o b / o b$ mice treated with leflunomide plus uridine than those treated with uridine alone (Supplementary Fig. 1, see section on supplementary data given at the end of this article). However, there was no significant difference in S6 and IRS-1 phosphorylation in the muscle, fat and liver between untreated and leflunomide-treated mice (Supplementary Fig. 2).

\section{Discussion}

S6K1 hyperactivation has been implicated in insulin resistance and the development of hyperglycemia and obesity (Um et al. 2004, 2006). S6K1-deficient mice are resistant to HFD-induced hyperglycemia and obesity (Um et al. 2004, 2006). Shum et al. (2016) recently reported that PF-4708671, an S6K1 inhibitor, controls hyperglycemia in HFD-fed mice by sensitizing the insulin receptor. We recently identified S6K1 as a molecular target of leflunomide and A77 1726 (Doscas et al. 2014). Inhibition of S6K1 activity by A77 1726 in A375 melanoma cells leads to the feedback activation of the PI-3 kinase pathway, as evidenced by increased $\mathrm{AKT}^{5473}$ and decreased S6 $6235 / 236$ phosphorylation. Our present study showed that inhibition of S6K1 activity by A77 1726 led to the inhibition of S6 $6^{5235 / 236}$ and IRS-1 ${ }^{51101}$ phosphorylation in mouse $\mathrm{C} 2 \mathrm{C} 12$ and rat L6 myotubes and in mouse 3T3-L1 adipocytes under normal and/or insulin resistance conditions. A77 1726 enhanced insulin-induced insulin receptor tyrosine phosphorylation, binding of the p85 subunit of the PI-3 kinase to IRS-1 (Fig. 5), and insulin-induced GLUT4 translocation to the plasma membrane in L6 cells in the presence of high amino acid concentrations (Fig. 6). Leflunomide treatment increased AKT $308 / 5473$ phosphorylation in the muscular and adipose 
A

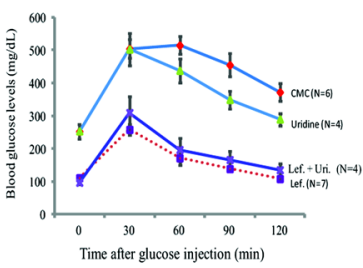

E

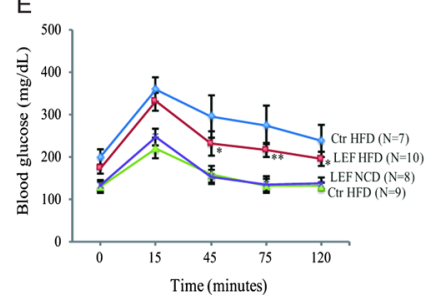

$B$
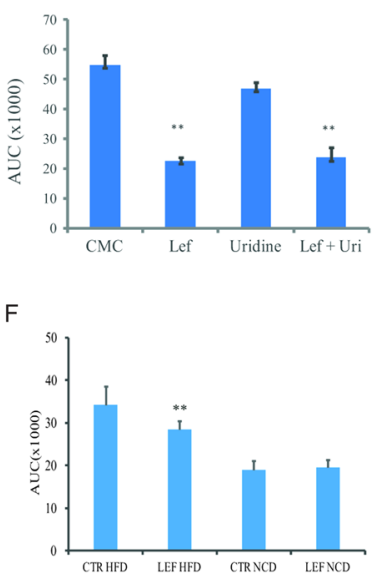

C
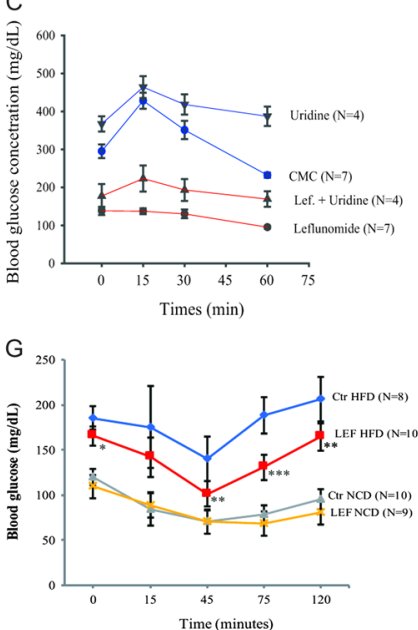

D

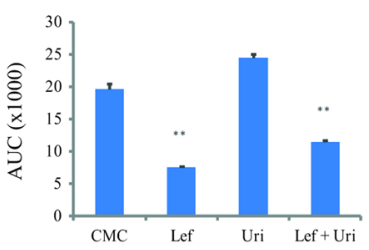

$\mathrm{H}$

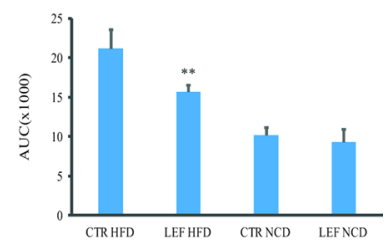

Figure 8

Control of hyperglycemia and insulin receptor sensitization by leflunomide. (A) ob/ob mice were treated as described in 'Materials and methods' section. The mice were challenged with glucose $(1 \mathrm{~g} / \mathrm{kg})$ by intraperitoneal injection for GTT. Blood glucose levels were measured at the indicated time. CMC vs leflunomide, uridine or leflunomide + uridine, $P<0.001$; leflunomide vs leflunomide + uridine, $P=0.002$. Lef, leflunomide; Uri, uridine; The arbitrary values of AUC were calculated and shown in a bar graph (B) ** CMC vs leflunomide or leflunomide + uridine, $P<0.001$; CMC vs uridine, $P=0.057$. (C) Control of hyperglycemia by leflunomide in ITT. ob/ob mice were treated as described in 'Materials and methods' section. After fasting for $6 \mathrm{~h}$, insulin $(2.5 \mathrm{U} / \mathrm{kg})$ was injected intravenously. Blood glucose levels were measured at the indicated times. CMC vs leflunomide, uridine or leflunomide + uridine, $P<0.001$; leflunomide vs leflunomide + uridine, $P=0.006$. (D) AUC in the different treatment groups was shown as the bar graph. ${ }^{*}$ CMC vs leflunomide or leflunomide + uridine, $P<0.001$; CMC vs uridine, $P=0.115$. (E and G) C57BL/6 male mice (5W-weeks-old) fed on normal chow diet (NCD) or high-fat diet (HFD) for 10 weeks were treated daily with CMC or leflunomide ( $35 \mathrm{mg} / \mathrm{kg} / \mathrm{day})$ for $3 \mathrm{days}$ and then evaluated for blood glucose levels in GTT (E) and ITT (G). (F and H) AUC in different treatment group was shown as bar graphs. ** CMC vs leflunomide in mice fed with HFD, $P<0.001$; CMC vs leflunomide in mice fed with NCD, $P>0.05$. A full colour version of this figure is available at https://doi.org/10.1530/ JOE-17-0536.

tissues in vivo (Fig. 9B). These observations collectively suggest that inhibition of S6K1 by A77 1726 is primarily responsible for its anti-hyperglycemic effect. Guo et al. (1997) reported earlier that chronic use of leflunomide has no effect on blood glucose levels in healthy rats. Because there is no insulin resistance in the insulinsensitive tissues of normal animals, leflunomide cannot further sensitize the insulin receptor. Consistently, we found that there was no significant difference in blood glucose levels in NCD-fed lean mice treated with CMC or leflunomide (Fig. 8E, F, G and H).

We investigated the inhibitory effect of A77 1726 on the phosphorylation of two relevant substrates of S6K1, S6 $6^{\text {S235/236 }}$ and IRS-1 ${ }^{\text {S1101. Due to feedback activation }}$ of the PI-3 kinase pathway, S6K1 phosphorylation was increased in A77 1726-treated cells. A77 1726 inhibited S6 $6^{\text {S235/236 }}$ and IRS-1 ${ }^{\text {S1101 }}$ phosphorylation in myotubes and adipocytes in vitro. In contrast, leflunomide treatment did not significantly decrease S6 $6^{\text {S235/236 }}$ and IRS-1 ${ }^{\text {S1101 in }}$ the metabolic tissues of insulin-stimulated mice in vivo (Supplementary Fig. 2). Similar to our observations, (Shum et al. 2016) reported that PF-4708671, a more potent inhibitor of S6K1 than A77 1726, did not inhibit S6 phosphorylation in vivo. These investigators suggest that compensatory S6K2 activation may shield the inhibitory effect of PF-4708671 on S6 phosphorylation (Shum et al. 2016). Pearce et al. (2010) reported that PF-4708671 did not inhibit early S6 phosphorylation in 293 cells in the presence of serum. We speculate that inhibition of S6K1 activity by A77 1726 or PF-4708671 may initially inhibit S6 and IRS-1 phosphorylation. However, when S6K1 is further feedback activated, incomplete inhibition of S6 activity may account for lack of inhibition of S6 and IRS-1 phosphorylation. Within a few minutes after insulin injection, leaked S6K1 activity is sufficient to fully phosphorylate S6 and IRS-1. However, once AKT is feedback activated, AKT phosphorylation levels will remain high for a while. Activated AKT continues to regulate glucose metabolism until it is dephosphorylated and inactivated. IRS-1 is phosphorylated at S636 by mTOR (Copps \& White 2012). Our present study showed that due to feedback activation of mTOR, A77 1726 induced IRS-1 ${ }^{5636}$ phosphorylation in C2C12 myotubes. Interestingly, IRS-1 ${ }^{\text {S636 }}$ phosphorylation by ROCK1 leads to the activation of PI-3 kinase (Copps \& White 2012). Thus, A77 1726 may improve insulin receptor signaling by inhibiting IRS-1 ${ }^{\text {S1101 }}$ and by increasing IRS-15636 phosphorylation. 
A
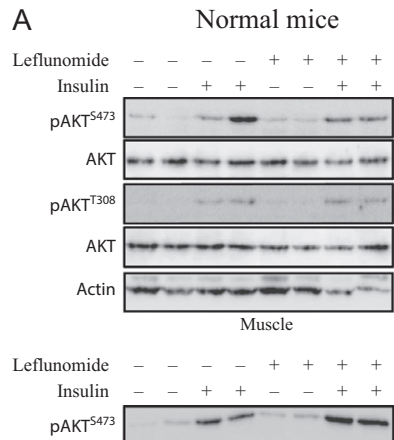

PAKT $^{\top 308}$

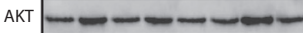

Actin

Fat

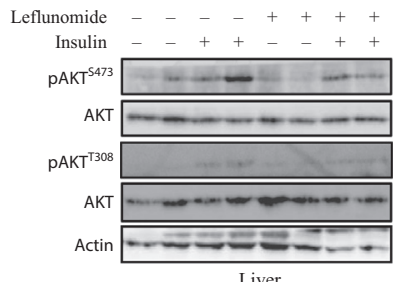

B
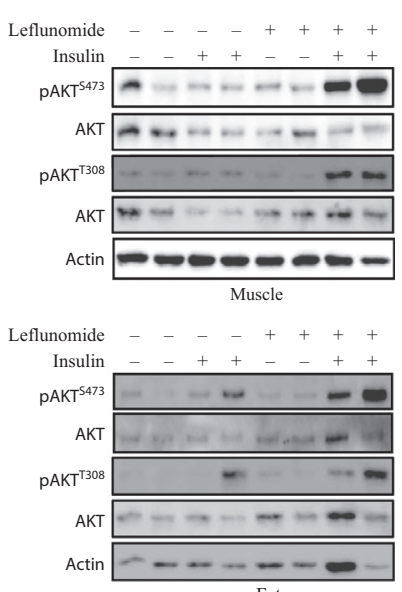

Fat

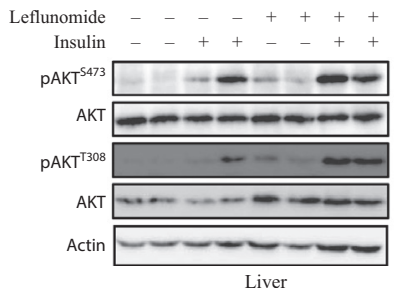

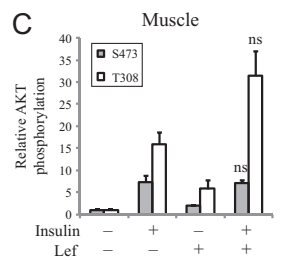

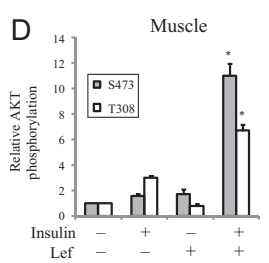

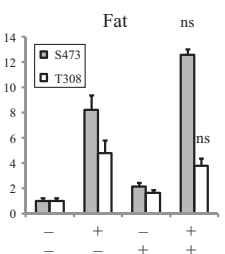
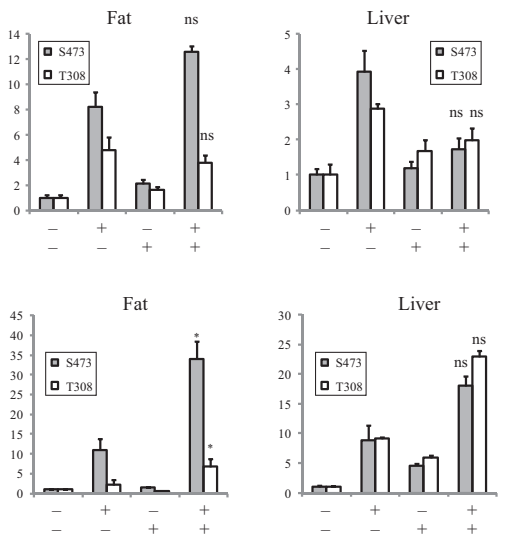

Figure 9

AKT phosphorylation in the metabolic tissues is enhanced by leflunomide. C57BL/6 (A) and ob/ob (B) mice were treated daily with CMC (1.5\%) or leflunomide ( $35 \mathrm{mg} / \mathrm{kg} / \mathrm{day}$ ) for 3 days. On day 4, the mice were treated with a last dose and then fasted for $6 \mathrm{~h}$. Mice were then injected intravenously with saline or insulin (2.5 unit/kg). Five minutes later, the mice were sacrificed. Gastrocnemius muscle, visceral white adipose and liver tissues were harvested and analyzed for AKT ${ }^{5473 \pi 308}$ phosphorylation by Western blot with their specific antibodies and reprobed with an antibody against total AKT protein. Immunoblots represent the data from two animals in each group. The experiment was repeated twice. (C and D) The density of the bands in the tissues of normal C57BL/6 mice (C) and ob/ob mice (D) was analyzed by using NIH Image-J software and normalized by the arbitrary units of their corresponding total proteins. The results are the mean \pm s.D. from four animals in each group. ${ }^{*} P<0.05$; ns, not significant between $\mathrm{CMC/insulin-treated}$ and leflunomide/insulin-treated group.

Leflunomide and A77 1726 inhibit S6K1 activity with the $\mathrm{IC}_{50}$ values of approximately 50-75 $\mu \mathrm{M}$ (Doscas et al. 2014). Plasma concentrations of A77 1726 in RA patients treated with leflunomide $(20 \mathrm{mg} /$ day $)$ are higher than $200 \mu \mathrm{M}$ (Chan et al. 2005). A77 1726 in the blood of mice treated with leflunomide at a dose of $35 \mathrm{mg} / \mathrm{kg}$ had a remarkably long half-life of $15 \mathrm{~h}$. The blood concentrations of A77 1726 reached a peak of $500 \mu \mathrm{M}$ within $4 \mathrm{~h}$ and remained at $250 \mu \mathrm{M}$ at $24 \mathrm{~h}$ after a single dose of $35 \mathrm{mg} / \mathrm{kg}$ of leflunomide in mice (Chong et al. 1999). These data suggest that A77 1726 concentrations in plasma are high enough to inhibit S6K1 activity. Indeed, AKT phosphorylation was increased in the metabolic tissues of leflunomide-treated mice. Blood glucose levels were decreased to normal levels in $o b / o b$ mice treated with leflunomide at a dose of $35 \mathrm{mg} / \mathrm{kg} /$ day. Co-administration with uridine was unable to block the anti-glycemic effect of leflunomide. An earlier clinical study revealed that the mean glucose levels in the blood of RA patients treated with leflunomide $(83 \mathrm{mg} / \mathrm{dL})$ were significantly lower than those treated with other regimens $(93 \mathrm{mg} / \mathrm{dL})$ (Rho et al. 2009). About $10 \%$ of patients treated with leflunomide undergo weight loss that cannot be attributed to diarrhea or other gastrointestinal side effects and is likely due to an increased metabolic rate (Coblyn et al. 2001). These observations collectively suggest that A77 1726 concentrations are high enough to inhibit S6K1 activity, subsequently leading to better control of hyperglycemia. Inflammatory cytokines, in particular TNF- $\alpha$, can also desensitize the insulin receptor and contribute to the development of hyperglycemia (Copps \& White 2012). Anti-TNF- $\alpha$ therapy does not lower blood glucose levels in RA patients (Rosenvinge et al. 2007). Many antiinflammatory drugs, unlike leflunomide, do not lower blood glucose levels (Rho et al. 2009), suggesting that inhibition of inflammation is not a sufficient explanation for better control of hyperglycemia.

We are aware of several weaknesses in our study. First, the evidence supporting the conclusion that leflunomide sensitized the insulin receptor and controlled 
hyperglycemia by inhibiting the activity of S6K1 in vivo is weak. Increased AKT phosphorylation in the tissue of leflunomide-treated mice with insulin resistance indirectly suggests feedback activation of the PI-3 kinase pathway due to the inhibition of S6K1 activity. However, inhibition of 56 and IRS-1 phosphorylation was not seen in the tissue of leflunomide-treated animals. This is consistent with the observations in a study using PF-4708671, a potent S6K1 inhibitor (Shum et al. 2016). Second, leflunomide worked extremely well in lowering blood glucose levels in the $o b / o b$ mice, even with a relatively small sample size, the $P$ values reached statistically significant levels. However, leflunomide only modestly decreased blood glucose levels in the GTT and ITT in the mouse model of the HFD-induced diabetes. Third, leflunomide treatment significantly enhanced insulin-stimulated AKT phosphorylation in the muscle and adipose tissues of $o b / o b$ mice. Leflunomide treatment increased AKT phosphorylation in the liver of $o b / o b$ mice, but this was not statistically significant due to a relatively small number of animals and the high variability of AKT phosphorylation. Fourth, since there are already many anti-diabetic drugs available for treating hyperglycemia, leflunomide might be only useful for a certain type of patient population such as those with both diabetes and RA. The diabetes mouse models used in our study do not have RA, thus not completely recapitulating a clinical setting in which leflunomide deems to be used.

Chronic use of rapamycin does not control but rather exacerbates hyperglycemia in mouse models and in patients (Di Paolo et al. 2006, Schindler et al. 2014). Failure of rapamycin to control hyperglycemia is, after chronic use, due to its ability to inhibit the activity of mTORC2 (Fig. 1B), which is responsible for phosphorylating AKT ${ }^{5473}$ (Lamming et al. 2012). In the present study, we did not follow-up the anti-hyperglycemic effect after chronic use of leflunomide. However, several lines of evidence suggest that chronic use of leflunomide will likely maintain its therapeutic efficacy: (1) Unlike rapamycin, A77 1726 inhibits S6K1 (Doscas et al. 2014), a kinase downstream of mTOR. Therefore, A77 1726 does not act like rapamycin to inhibit mTORC2 (Fig. 1B); (2) The anti-hyperglycemic effect of PF-4708671 after chronic use is sustainable in vivo (Shum et al. 2016). Both A77 1726 and PF-4708671 control hyperglycemia by inhibiting S6K1; (3) Blood glucose levels are significantly lower in RA patients chronically treated with leflunomide than those treated with other drugs (Rho et al. 2009). Nevertheless, whether leflunomide can maintain a long-lasting therapeutic effect after chronic use should be verified first in animal models before it can be investigated in patients.
In summary, our present study showed that A77 1726 induced feedback activation of the PI-3 kinase pathway by inhibiting S6K1 activity and that A77 1726 increased glucose uptake and GLUT4 translocation to the plasma membrane in vitro (Fig. 1B). A77 1726 may also improve glucose metabolisms by stimulating glycogen synthesis and by inhibiting gluconeogenesis through activated AKT (Fig. 1B). Leflunomide was capable of controlling hyperglycemia and improving insulin sensitivity in vivo. Leflunomide could be particularly useful for treating RA patients who also have type 2 diabetes.

\section{Supplementary data}

This is linked to the online version of the paper at https://doi.org/10.1530/ JOE-17-0536.

\section{Declaration of interest}

The authors declare that there is no conflict of interest that could be perceived as prejudicing the impartiality of the research reported.

\section{Funding}

This work was supported by grants from Rush Pilot Diabetes Research fund, Natural Science Foundation of China (81672463) and the Priority Academic Program Development of Jiangsu Higher Education Institutions to X Xu, and by an NIH R01 (CA204926) grant to Y Li.

\section{Author contribution statement}

$\mathrm{X} X$ conceived concept, wrote manuscript and researched data. J C; J S, M E D, J Y; A J W conducted experiments and contributed to discussion; Y L (University of Chicago) contributed to discussion; Y L (Baylor College of Medicine) R A P contributed to discussion, reviewed and edited the manuscript.

\section{Acknowledgements}

The authors are very grateful to $\mathrm{Dr}$ James W. Williams in CinKate Corporation for kindly providing A77 1726 and leflunomide and Dr Amira Klip (The Hospital for Sick Children, Toronto, Ontario) for mCherry-GLUT4myc expression vector.

\section{References}

Boura-Halfon S \& Zick Y 2009 Phosphorylation of IRS proteins, insulin action, and insulin resistance. American Journal of PhysiologyEndocrinology and Metabolism 296 E581-E591. (https://doi. org/10.1152/ajpendo.90437.2008)

Breedveld FC \& Dayer JM 2000 Leflunomide: mode of action in the treatment of rheumatoid arthritis. Annals of the Rheumatic Diseases 59 841-849. (https://doi.org/10.1136/ard.59.11.841) 
Bruneau JM, Yea CM, Spinella-Jaegle S, Fudali C, Woodward K, Robson PA, Sautes C, Westwood R, Kuo EA, Williamson RA, et al. 1998 Purification of human dihydro-orotate dehydrogenase and its inhibition by A77 1726, the active metabolite of leflunomide. Biochemical Journal 336 299-303. (https://doi.org/10.1042/ bj3360299)

Cannon GW \& Kremer JM 2004 Leflunomide. Rheumatic Diseases Clinics of North America 30 295-309. (https://doi.org/10.1016/j. rdc.2004.01.010)

Chan V, Charles BG \& Tett SE 2005 Population pharmacokinetics and association between A77 1726 plasma concentrations and disease activity measures following administration of leflunomide to people with rheumatoid arthritis. British Journal of Clinical Pharmacology 60 257-264. (https://doi.org/10.1111/j.1365-2125.2005.02415.x)

Chong AS, Huang W, Liu W, Luo J, Shen J, Xu W, Ma L, Blinder L, Xiao F, $\mathrm{Xu}$ X, et al. 1999 In vivo activity of leflunomide: pharmacokinetic analyses and mechanism of immunosuppression. Transplantation 68 100-109. (https://doi.org/10.1097/00007890-199907150-00020)

Coblyn JS, Shadick N \& Helfgott S 2001 Leflunomide-associated weight loss in rheumatoid arthritis. Arthritis and Rheumatology 44 1048-1051. (https://doi.org/10.1002/1529-0131(200105)44:5<1048::AIDANR184>3.0.CO;2-V)

Copps KD \& White MF 2012 Regulation of insulin sensitivity by serine/ threonine phosphorylation of insulin receptor substrate proteins IRS1 and IRS2. Diabetologia 55 2565-2582. (https://doi.org/10.1007/ s00125-012-2644-8)

Dann SG, Selvaraj A \& Thomas G 2007 mTOR Complex1-S6K1 signaling: at the crossroads of obesity, diabetes and cancer. Trends in Molecular Medicine 13 252-259. (https://doi.org/10.1016/j.molmed.2007.04.002)

Di Paolo S, Teutonico A, Leogrande D, Capobianco C \& Schena PF 2006 Chronic inhibition of mammalian target of rapamycin signaling downregulates insulin receptor substrates 1 and 2 and AKT activation: a crossroad between cancer and diabetes? Journal of the American Society of Nephrology 17 2236-2244. (https://doi.org/10.1681/ ASN.2006030196)

Doscas ME, Williamson AJ, Usha L, Bogachkov Y, Rao GS, Xiao F, Wang Y, Ruby C, Kaufman H, Zhou J, et al. 2014 Inhibition of p70 S6 kinase (S6K1) activity by A77 1726 and its effect on cell proliferation and cell cycle progress. Neoplasia 16 824-834. (https://doi.org/10.1016/j. neo.2014.08.006)

Elder RT, Xu X, Williams JW, Gong H, Finnegan A \& Chong AS 1997 The immunosuppressive metabolite of leflunomide, A77 1726, affects murine $\mathrm{T}$ cells through two biochemical mechanisms. Journal of Immunology 159 22-27.

Fenton TR \& Gout IT 2010 Functions and regulation of the 70kDa ribosomal S6 kinases. International Journal of Biochemistry and Cell Biology 43 47-59. (https://doi.org/10.1016/j.biocel.2010.09.018)

Guo S 2013 Molecular basis of insulin resistance: the role of IRS and Foxo1 in the control of diabetes mellitus and its complications. Drug Discovery Today: Disease Mechanisms 10 e27-e33. (https://doi. org/10.1016/j.ddmec.2013.06.003)

Guo S 2014 Insulin signaling, resistance, and the metabolic syndrome: insights from mouse models into disease mechanisms. Journal of Endocrinology 220 T1-T23. (https://doi.org/10.1530/JOE-13-0327)

Guo Z, Chong AS, Shen J, Foster P, Sankary HN, McChesney L, Mital D, Jensik SC, Gebel H \& Williams JW 1997 In vivo effects of leflunomide on normal pancreatic islet and syngeneic islet graft function. Transplantation 63 716-721. (https://doi.org/10.1097/00007890199703150-00018)

He J, Gao J, Xu M, Ren S, Stefanovic-Racic M, O’Doherty RM \& Xie W 2013 PXR ablation alleviates diet-induced and genetic obesity and insulin resistance in mice. Diabetes 62 1876-1887. (https://doi. org/10.2337/db12-1039)

Herlitz-Cifuentes HS, Garces PC, Fernandez LI \& Guzman-Gutierrez EA 2015 Effect of systemic inflammation on the function of insulin and glucose metabolism in rheumatoid arthritis. Current Diabetes Reviews
12 156-162. (https://doi.org/10.2174/15733998116661506021 50325)

Jiang P, Li H \& Li X 2015 Diabetes mellitus risk factors in rheumatoid arthritis: a systematic review and meta-analysis. Clinical and Experimental Rheumatology 33 115-121.

Lamming DW, Ye L, Katajisto P, Goncalves MD, Saitoh M, Stevens DM, Davis JG, Salmon AB, Richardson A, Ahima RS, et al. 2012 Rapamycininduced insulin resistance is mediated by mTORC2 loss and uncoupled from longevity. Science 335 1638-1643. (https://doi. org/10.1126/science.1215135)

Nathan DM 2015 Diabetes: advances in diagnosis and treatment. JAMA 314 1052-1062. (https://doi.org/10.1001/jama.2015.9536)

Patti ME, Brambilla E, Luzi L, Landaker EJ \& Kahn CR 1998 Bidirectional modulation of insulin action by amino acids. Journal of Clinical Investigation 101 1519-1529. (https://doi.org/10.1172/JCI1326)

Pearce LR, Alton GR, Richter DT, Kath JC, Lingardo L, Chapman J, Hwang C \& Alessi DR 2010 Characterization of PF-4708671, a novel and highly specific inhibitor of p70 ribosomal S6 kinase (S6K1). Biochemical Journal 431 245-255. (https://doi.org/10.1042/ BJ20101024)

Pinto AJ, Roschel H, de Sa Pinto AL, Lima FR, Pereira RMR, Silva CA, Bonfa E \& Gualano B 2017 Physical inactivity and sedentary behavior: overlooked risk factors in autoimmune rheumatic diseases? Autoimmunity Reviews 16 667-674. (https://doi.org/10.1016/j. autrev.2017.05.001)

Rho YH, Oeser A, Chung CP, Milne GL \& Stein CM 2009 Drugs used in the treatment of rheumatoid arthritis: relationship between current use and cardiovascular risk factors. Archives of Drug Information 2 34-40. (https://doi.org/10.1111/j.1753-5174.2009.00019.x)

Rosenvinge A, Krogh-Madsen R, Baslund B \& Pedersen BK 2007 Insulin resistance in patients with rheumatoid arthritis: effect of antiTNFalpha therapy. Scandinavian Journal of Rheumatology 36 91-96. (https://doi.org/10.1080/03009740601179605)

Ruckemann K, Fairbanks LD, Carrey EA, Hawrylowicz CM, Richards DF, Kirschbaum B \& Simmonds HA 1998 Leflunomide inhibits pyrimidine de novo synthesis in mitogen-stimulated T-lymphocytes from healthy humans. Journal of Biological Chemistry 273 21682-21691. (https:// doi.org/10.1074/jbc.273.34.21682)

Schindler CE, Partap U, Patchen BK \& Swoap SJ 2014 Chronic rapamycin treatment causes diabetes in male mice. American Journal of Physiology: Regulatory, Integrative and Comparative Physiology 307 R434-R443. (https://doi.org/10.1152/ajpregu.00123.2014)

Selman C, Tullet JM, Wieser D, Irvine E, Lingard SJ, Choudhury AI, Claret M, Al-Qassab H, Carmignac D, Ramadani F, et al. 2009 Ribosomal protein S6 kinase 1 signaling regulates mammalian life span. Science 326 140-144. (https://doi.org/10.1126/science.1177221)

Shum M, Bellmann K, St-Pierre P \& Marette A 2016 Pharmacological inhibition of S6K1 increases glucose metabolism and Akt signalling in vitro and in diet-induced obese mice. Diabetologia 59 592-603. (https://doi.org/10.1007/s00125-015-3839-6)

Siemasko KF, Chong AS, Williams JW, Bremer EG \& Finnegan A 1996 Regulation of B cell function by the immunosuppressive agent leflunomide. Transplantation 61 635-642. (https://doi. org/10.1097/00007890-199602270-00020)

Siemasko K, Chong AS, Jack HM, Gong H, Williams JW \& Finnegan A 1998 Inhibition of JAK3 and STAT6 tyrosine phosphorylation by the immunosuppressive drug leflunomide leads to a block in IgG1 production. Journal of Immunology 160 1581-1588.

Um SH, Frigerio F, Watanabe M, Picard F, Joaquin M, Sticker M, Fumagalli S, Allegrini PR, Kozma SC, Auwerx J, et al. 2004 Absence of S6K1 protects against age- and diet-induced obesity while enhancing insulin sensitivity. Nature 431 200-205. (https://doi.org/10.1038/ nature02866)

Um SH, D'Alessio D \& Thomas G 2006 Nutrient overload, insulin resistance, and ribosomal protein S6 kinase 1, S6K1. Cell Metabolism 3 393-402. (https://doi.org/10.1016/j.cmet.2006.05.003)
๑) 2018 Society for Endocrinology Published by Bioscientifica Ltd. Printed in Great Britain 
Versini M, Jeandel PY, Rosenthal E \& Shoenfeld Y 2014 Obesity in autoimmune diseases: not a passive bystander. Autoimmunity Reviews 13 981-1000. (https://doi.org/10.1016/j.autrev.2014.07.001)

Williamson RA, Yea CM, Robson PA, Curnock AP, Gadher S, Hambleton AB, Woodward K, Bruneau JM, Hambleton P, SpinellaJaegle S, et al. 1996 Dihydroorotate dehydrogenase is a target for the biological effects of leflunomide. Transplantation Proceedings $\mathbf{2 8}$ 3088-3091.

Xia T, Cheng Y, Zhang Q, Xiao F, Liu B, Chen S \& Guo F 2012 S6K1 in the central nervous system regulates energy expenditure via MC4R/ $\mathrm{CRH}$ pathways in response to deprivation of an essential amino acid. Diabetes 61 2461-2471. (https://doi.org/10.2337/db11-1278)

Xu X, Williams JW, Bremer EG, Finnegan A \& Chong AS 1995 Inhibition of protein tyrosine phosphorylation in $\mathrm{T}$ cells by a novel immunosuppressive agent, leflunomide. Journal of Biological Chemistry 270 12398-12403. (https://doi.org/10.1074/ jbc.270.21.12398)

Xu X, Williams JW, Gong H, Finnegan A \& Chong AS 1996 Two activities of the immunosuppressive metabolite of leflunomide, A77 1726. Inhibition of pyrimidine nucleotide synthesis and protein tyrosine phosphorylation. Biochemical Pharmacology 52 527-534. (https://doi. org/10.1016/0006-2952(96)00303-6)

Xu X, Blinder L, Shen J, Gong H, Finnegan A, Williams JW \& Chong AS 1997 In vivo mechanism by which leflunomide controls lymphoproliferative and autoimmune disease in MRL/MpJ-lpr/lpr mice. Journal of Immunology 159 167-174.

Xu X, Shen J, Mall JW, Myers JA, Huang W, Blinder L, Saclarides TJ, Williams JW \& Chong AS 1999 In vitro and in vivo antitumor activity of a novel immunomodulatory drug, leflunomide: mechanisms of action. Biochemical Pharmacology 58 1405-1413. (https://doi. org/10.1016/S0006-2952(99)00228-2)

Zebisch K, Voigt V, Wabitsch M \& Brandsch M 2012 Protocol for effective differentiation of 3T3-L1 cells to adipocytes. Analytical Biochemistry 425 88-90. (https://doi.org/10.1016/j.ab.2012.03.005)

Zimmet P, Alberti KG \& Shaw J 2001 Global and societal implications of the diabetes epidemic. Nature $\mathbf{4 1 4}$ 782-787. (https://doi. org/10.1038/414782a)

Zimmet PZ, Magliano DJ, Herman WH \& Shaw JE 2014 Diabetes: a 21st century challenge. Lancet Diabetes and Endocrinology 2 56-64. (https:// doi.org/10.1016/S2213-8587(13)70112-8)

Received in final form 4 January 2018

Accepted 7 February 2018 http://joe.endocrinology-journals.org https://doi.org/10.1530/JOE-17-0536
๑) 2018 Society for Endocrinology Published by Bioscientifica Ltd. Printed in Great Britain 